\title{
Religion between Politics and Media: Conflicting Attitudes towards Islam in Scandinavia
}

\author{
Knut Lundby \\ Department of Media and Communication, University of Oslo \\ knut.lundby@media.uio.no \\ Stig Hjarvard \\ Department of Media, Cognition and Communication, University of \\ Copenhagen \\ stig@hum.ku.dk \\ Mia Lövheim \\ Sociology of Religion, Department of Theology, Uppsala University \\ mia.lovheim@teol.uu.se \\ Haakon H.Jernsletten \\ Department of Media and Communication, University of Oslo \\ h.h.jernsletten@media.uio.no
}

\begin{abstract}
Based on a comparative project on media and religion across Denmark, Norway, and Sweden, this article analyzes relationships between religiosity and political attitudes in Scandinavia and how these connect with attitudes regarding the representation of Islam in various media. Data comes from population-wide surveys conducted in the three countries in April 2015. Most Scandinavians relate 'religion' with conflict, and half of the population perceives Islam as a threat to their national culture. Scandinavians thus perceive religion in terms of political tensions and predominantly feel that news media should serve a critical function towards Islam and religious conflicts. Finally, the results of the empirical analysis are discussed in view of the intertwined processes of politicization of Islam and mediatization of religion.
\end{abstract}




\section{Keywords}

media - religion - Islam - Scandinavia - conflict - mediatization

\section{Introduction}

In this article, we present an analysis of attitudes towards religion and religious conflicts in the three Scandinavian countries: Denmark, Norway, and Sweden. Our analysis focuses on how critical attitudes towards Islam and immigrants are related to religious self-identification and political orientation. The study considers whether groups with different viewpoints on these issues differ in their attitudes towards media representations of religion. We also pay attention to the role of media as sources of information concerning religion and as platforms for discussing conflicts related to religion.

Our study concerns different forms of media. Since several of the survey questions consider public representation and debate about religion, 'news media' are often the focus, in other cases 'public service' media or 'social network media' are specifically addressed. When we do not specify a media form, we have asked the respondents about their attitudes towards and impressions from 'the media' in general. As Scandinavians live in a media-saturated environment it is not always possible for people to specify their media sources.

\section{2 \\ Background: Religion between Politics and Media}

In a European context, Scandinavian countries are, comparatively speaking, highly secularized yet influenced by a long history of Protestant Christianity as a dominant national religion that was, until recently, institutionalized as state churches. ${ }^{1}$ A common Christian cultural heritage and shared secular values are still important characteristics of Scandinavian populations. But, developments over the past decades have also demonstrated that the three Scandinavian countries have to some extent moved in different directions with regard to attitudes towards religion, in particular Islam, and its presence in the media and other parts of the public sphere. These developments in part concern the growing number of migrants and refugees entering Scandinavian countries,

1 Regarding the point of Scandinavian countries as secularized, see World Values Survey. http://www.worldvaluessurvey.org/WVSContents.jsp (accessed 18 April 2017). The majority church in Denmark is still a state church. 
the rise of right-wing populist parties, the international war on terror in general, and the advent of major terrorist attacks in particular.

Over the past decade, the three Scandinavian countries have experienced increased levels of immigration, with a new wave of refugees arriving since the summer of 2015. This has led to a more restricted policy towards immigrants and refugees in all three Scandinavian countries, including tighter border controls. Sweden has for years had the largest number of refugees and other immigrants, even in terms of share of the total population. ${ }^{2}$ At the peak in 2015, a total of 162,877 asked for asylum in Sweden. ${ }^{3}$ Refugees fleeing conflicts in the Middle East, most prominently in Syria, along with conflicts and terrorist attacks related to Islam, have resulted in an increased focus on the role of religion in the public sphere in all three countries.

The growing focus on Islam in news media is documented by a study comparing religion in the daily press in Denmark, Finland, Iceland, Norway, and Sweden. ${ }^{4}$ Coverage of Islam increased from four percent of all newspaper articles on religion in 1988 to thirteen percent in 2008, when looking at the Nordic countries as a whole. ${ }^{5}$ Coverage of Islam in news and debate articles focuses mainly on international conflicts, but recent years have seen increasing focus on issues related to integration and discrimination. There are distinct national variations. In Danish newspapers, Islam represents the most prominent segment of religion coverage.

During the same period, religion has become a more frequent theme in Scandinavian politics. References to religion in parliamentary debates have increased in Denmark, Norway, and Sweden. Many political parties express a positive attitude towards religious diversity, but religion has also been increasingly associated with international conflicts and fundamentalism. Right-wing populist parties have increased their support and gained seats in parliament in Denmark since 1998, Norway since 1997, and Sweden since 2010. These parties

2 Silje Vatne Pettersen \& Lars Østby, "Skandinavisk komparativ statistikk om integrering: Innvandrere i Norge, Sverige og Danmark," Samfunnsspeilet 5 (Oslo: Statistics Norway, 2013), $76-82$.

3 Migrationsinfo.se. http://www.migrationsinfo.se/migration/sverige/ (accessed 18 April 2017).

4 Knut Lundby et al., "Religion and the Media: Continuity, Complexity and Mediatization," in: Inger Furseth (ed.), Religious Complexity in the Public Sphere: Comparing Nordic Countries (Basingtoke: Palgrave Macmillan, 2018), Chapter 5; Kati Niemelä \& Henrik Reintoft Christensen, "Religion in Newspapers in the Nordic Countries in 1988-2008," Nordic Journal of Religion and Society $26 / 1$ (2013), 5-24.

5 Lundby et al., "Religion and the Media." In comparison, coverage of the dominant Lutheran majority churches remains strong but has decreased from fifty-seven percent to forty-two percent of all main articles reporting on religion over the same period. 
politicize religion through an explicit equation of Christianity with national identity and through harsh criticism of Islam as associated with international and domestic conflicts. ${ }^{6}$

In this article, we consider the growing politicization of Islam in light of the ways in which news media and social media are implicated in conflicts relating to religion, particularly Islam. ${ }^{7}$ Theories of mediatization and mediatization of religion point to media's role in the construction of religion in contemporary society, including the ways in which media have become important sources of information about religious issues, as well as tools for active engagement with religion. ${ }^{8}$ Media are not neutral tools of communication but play an active, constitutive role in how religion and conflicts over religion play out. The Mohammed cartoon crisis in 2005-2006 and the Charlie Hebdo terrorist attack in 2015 are exemplary cases of how mediated representations of religion can become the very object of religious conflict. However, the media-influenced perceptions of religion and how these perceptions are acted upon occur in less spectacular circumstances as well.

We use mediatization theory to discuss the media's role as sources of information concerning religion and as platforms for representing and discussing religion and political conflict associated with religion, against the background of attitudes towards religion, particularly Islam, in the Scandinavian countries. What perceptions exist regarding the news media's role in relation to reporting, criticism, and tolerance of religion, and are such perceptions of the media's role related to religious or political viewpoints?

Our aim with this article is primarily descriptive. This contribution has to be elaborated upon in later analyses. Here, we focus on the most distinct similarities and differences in experiences, interpretations, and interactions concerning religion, politics, media, and conflict in Denmark, Norway, and Sweden.

6 Jonas Lindberg, Religion in Nordic Politics as a Means to Societal Cohesion: An Empirical Study on Party Platforms and Parliamentary Debates 1988-2012. Studies in Religion and Society 13 (Uppsala: Acta Universitatis Upsaliensis, 2015).

7 Regarding the politicization of religion, see Carolina Ivanescu, "Politicised Religion and the Religionisation of Politics," Culture and Religion 11/4 (2010), 309-325.

8 Stig Hjarvard \& Mia Lövheim (eds.), Mediatization and Religion: Nordic Perspectives (Gothenburg: Nordicom, 2012); Stig Hjarvard, The Mediatization of Culture and Society (London: Routledge, 2013); Knut Lundby (ed.), Mediatization of Communication. Handbooks of Communication Science 21 (Berlin: De Gruyter Mouton, 2014); Mia Lövheim, "Mediatization and Religion," in: Knut Lundby (ed.), Mediatization of Communication. Handbooks of Communication Science 21 (Berlin: De Gruyter Mouton, 2014, 547-570). 
These countries, with their similar cultural attributes and institutional arrangements, can be seen as a particularly good case for comparative analysis. ${ }^{9}$

\section{A Cross-National Scandinavian Survey}

We present and discuss the findings of a survey with nationwide representative samples of the adult populations of Denmark, Norway, and Sweden. This comparative survey is the first in Scandinavia to measure experiences of mediated religion in everyday life in terms of attitudes towards the representation of Islam, Judaism, and Christianity in the media, as well as uses of the media as a platform for discussing religion and religious extremism. The survey thus offers an opportunity to further understand relationships between political orientation, religious self-identification, and attitudes towards the media in Scandinavia. The survey was undertaken using web panels of around 1000 respondents aged sixteen years or above in each country. ${ }^{10}$

The survey discloses that, in the Scandinavian setting, attitudes towards and debates on religion in the public sphere, particularly in the news media, focus on Islam. This will form the center of our analyses. Because the survey was undertaken in April 2015, it cannot account for possible changes in attitudes regarding migrants generated by the strong increase in those seeking asylum in Sweden, Denmark, and Norway in the latter half of 2015. The survey is part of the project Engaging with Conflicts in Mediatized Religious Environments (CoMRel). ${ }^{11}$ This project aims to examine how religion in public spaces becomes thematized and enacted through the (news) media, as well as further articulated in face-to-face social interaction or through social media. ${ }^{12}$

9 Erik Damgaard, "Parliamentary Change in the Nordic Countries," in: Erik Damgaard et al. (eds.), Parliamentary Change in the Nordic Countries (Oslo: Scandinavian University Press, 1992, 191-205). See also Lindberg, Religion in Nordic Politics.

10 TNS Gallup (in Norway and Denmark) and tNs Sifo (in Sweden). Data gathered 16-21 April 2015. All data has been weighted by gender, age, and geographical region to ensure that the samples are as representative as possible, however, the samples were not weighted by education. CoMRel researchers, in cooperation with TNs staff, formulated the questions. The survey is documented in Norwegian on the CoMRel web. See Knut Lundby \& Salve Jortveit, Dokumentasjon av CoMRel survey april 2015. www.hf.uio.no/imk/english/ research/projects/comrel/comrel-survey-dokumentasjon.pdf (accessed 18 April 2017).

11 This is a comparative Scandinavian study, funded by the Research Council of Norway under the Programme on the Cultural Conditions Underlying Social Change (SAM KUL).

12 Knut Lundby (ed.), Contesting Religion: The Media Dynamics of Cultural Conflicts in Scandinavia (Berlin: De Gruyter, forthcoming 2018). 
In the following, we first present relationships between political orientation and religious self-identification in the Scandinavian countries. Then, we present findings on how Scandinavians view religion in the media and their expectations for media coverage of religion. We also show whether and where news on religion is discussed in the media. Finally, we relate these findings to attitudes towards religion and national culture in the Scandinavian countries. In the conclusion, we discuss similarities and differences between the countries and how politicization of religion may relate to the mediatized conditions of religion, particularly the workings of the news media.

\section{Political Orientation and Religious Self-Identification}

In order to describe a respondent's political orientation, we constructed a variable based on information from Chapel Hill Expert Survey (CHES) in 2014 and the respondent's answer concerning which political party he or she would vote for if an election were held today. ${ }^{13}$ We have placed the survey answers in one of three categories in terms of views on democratic freedoms and rights: 'libertarian/post-materialist,' 'center,' or 'traditional/authoritarian.'14 The distributions of respondents in the three Scandinavian countries are shown in Figure 1.

In Denmark, there is a stronger tendency towards polarization between libertarian/post-materialist and traditional/authoritarian political orientations than is present in Norway and Sweden. In these two countries, the 'center' holds more ground as over half of the voters align with political parties in the middle of this spectrum.

It is difficult to grasp people's religiosity using surveys. In this study, we follow a common practice in studies of individual religiosity by starting with a respondent's self-identification. On the basis of the options of identifying as 'religious' and being a 'believer,' we constructed a variable that describes

13 Ryan Bakker et al., Chapel Hill Expert Survey-Version 2015.1 (Chapel Hill: University of North Carolina, 2015). http://chesdata.eu/2014/2014_CHES_codebook.pdf (accessed 18 April 2017).

14 The categories are based on CHEs's expert coding of party positions in terms of views on democratic freedoms and rights (the GAL-TAN 11-point scale). Examples of 'libertarian/ post-materialist' parties include Enhedslisten and Liberal Alliance in Denmark, Venstre in Norway, and Vänsterpartiet and Miljöpartiet de Gröna in Sweden. Examples of 'traditional/ authoritarian' parties include Dansk Folkeparti in Denmark and Kristelig Folkeparti and Fremskrittspartiet in Norway, as well as Sverigedemokraterna in Sweden. Parties that occupy the 'center' include Socialdemokraterna and Venstre in Denmark, Arbeiderpartiet and Høyre in Norway, and Socialdemokraterna and Moderaterna in Sweden. 

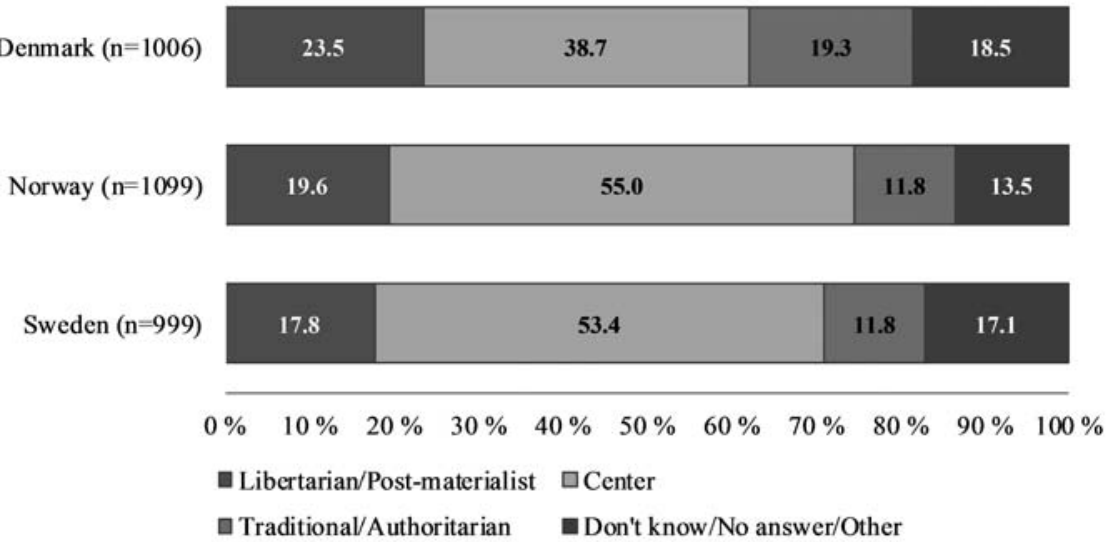

FIGURE 1 Political orientation in Scandinavia (GAL-TAN scale)—percentages

Note: A respondent is classified as 'libertarian/post-materialist' if his or her preferred party scores between 0 and 3 on the GAL-TAN scale, 'center' if the party scores between 3.01 and 6.99, and 'traditional/authoritarian' if the party scores between 7 and 10. 'Other' includes respondents who would not vote or would vote for a party not included in the survey.

a respondent's strength of religious self-identification. ${ }^{15}$ Those respondents with a 'strong or moderate' religious self-identification fully or to some extent identify themselves with these terms. Those with a 'weaker or no' religious selfidentification do not or only to a small extent regard themselves as 'religious' or 'believers.'

Exactly one-third of the Scandinavian respondents, considered as a whole, can be categorized as possessing strong or moderate religious self-identification while two-thirds possess weaker or no religious self-identification. As shown in Figure 2, religious self-identification is weaker among Swedes than among Danes and Norwegians. In all three countries, strong or moderate religious self-identification is more prevalent among women than among men.

There is a weak but significant positive correlation between 'political orientation' and 'religious self-identification': this is strongest in Norway (.228)

15 In the survey, we asked several questions on how respondents defined themselves in relation to religion. Following a factor analysis of several components related to religious selfidentification, we constructed a new variable on the basis of the following two questions: 'To what extent do you regard yourself as religious?'; and 'To what extent do you regard yourself as a believer?' From the context in which the two questions were posed and from the correlation between them, we are able to assume that self-identification as a 'believer' comes close to the category of 'religious.' 


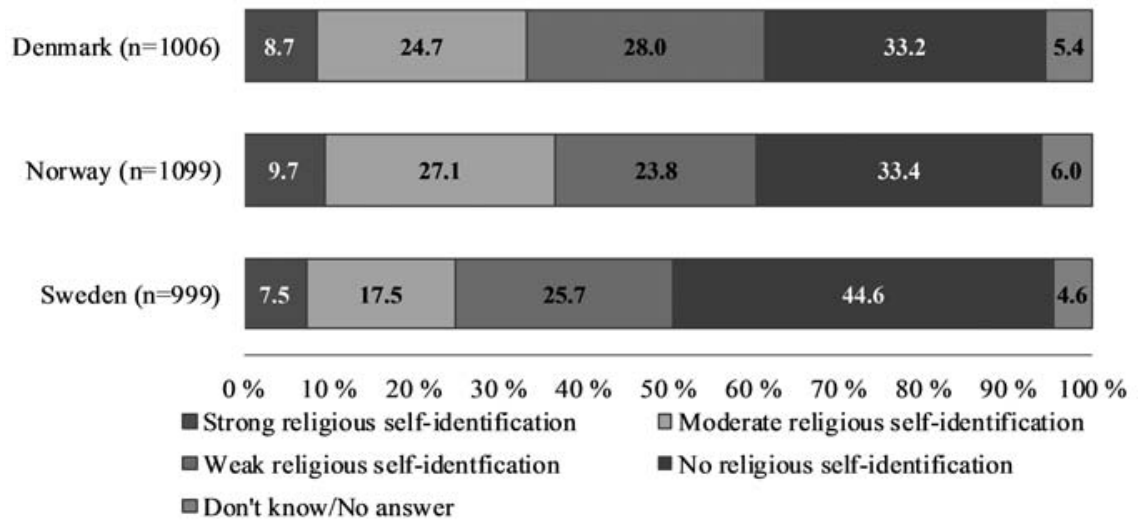

FIGURE 2 Religious self-identification in Scandinavia-percentages

and weakest in Sweden (.119), with Denmark in the middle (.177).${ }^{16}$ Among Norwegian and Danish respondents, those with stronger religious self-identification orient themselves more towards traditional/authoritarian political values than those with weaker religious self-identification. Conversely, respondents with weaker religious self-identification orient themselves more towards libertarian/post-materialist values than those with stronger religious self-identification.

\section{$5 \quad$ Religion in the Media: A Matter of News and Political Issues}

Despite the increased focus on Islam in Scandinavian news media, Scandinavians do not favor 'religion' as a designated media topic in general. Respondents were asked to rank their interest in the following eight categories of topics within 'the media': culture, business, politics, religion, sex and partnership, sports, entertainment, and science. In Denmark and Sweden, religion was ranked last on average, and religion was ranked second to last on average in Norway. Although Scandinavians place low priority on 'religion' as a designated dish in their general media diet, around half of the adult Scandinavian population discusses news concerning religion on at least a monthly basis. More than

16 Political orientation $=\mathrm{GAL} / \mathrm{TAN}$ score $(0-10)$. Religious self-identification: $0=$ no religious self-identification; 1 = weak religious self-identification; 2 = moderate religious self-identification; and $3=$ strong religious self-identification. All correlations (Pearson's r) are significant at the o.o1-level (two-tailed). 
one in four Scandinavians share their thoughts and concerns regarding news on religion with others on a daily or weekly basis. ${ }^{17}$

When asked what aspects of religion they are most interested in finding in the media in general, 'religion in the news' is the top priority, before 'religion and politics.' These are followed by 'religion and culture,' then 'religion as moral reflection,' and then 'religion in entertainment.' At the bottom of the list comes 'worship and devotions.' The ranking is the same in all three countries.

Thus, for Scandinavians, religion in the media is primarily a topic in the news and a matter of politics and culture in the widest sense rather than a personal matter of spirituality, reflection, and belief.

\section{The Media Expected to Be Critical towards Religion}

Respondents in Denmark, Norway, and Sweden were asked several questions on what 'the media' ought to do in the coverage of religion. The questions are asked on 'the media' in general but may for most people connote mass media and more specifically news media. The answers can be compared as all questions used the same scale, ranging from 'fully agree' to 'partly agree' to 'neither/ nor' to 'partly disagree' to 'fully disagree.' Table 1 shows the combined percentages of those who 'fully' or 'partly' agree with the various statements. Those who do not know what to answer or do not want to answer are included in the tabulations. The figures in Table 1 thus show explicit support for the statements among all respondents in the three countries.

If respondents understand 'religious topics' as relating to particular beliefs, Table 1 confirms the low interest disclosed above even though one in four individuals feels that the media should give more attention to religious topics.

Scandinavians are more positive towards the media critically examining Islam, Judaism, and Christianity than they are towards more extensive media coverage of these religions. Norwegians expect the media to be more critical than do their neighbors. While half of all Norwegians think that the media should be more critical of Islam, only a quarter would like to learn more about Islam from broader coverage.

Again, religion arises as a matter of public concern and critique. Scandinavians would like the media to be critical towards religion and cover conflicts and problematic aspects concerning religion. However, the media are expected to invite dialogue over tensions related to religion. On all of these

17 Denmark 28.0\%, Norway 29.9\%, Sweden 27.7\%. 'Don't know' and 'do not want to answer' were included in the tabulation. 
TABLE 1 Percentage of the respondents who fully or partly agree with statements on what the media ought to do in their coverage of religion

The media ought to...

DENMARK NORWAY SWEDEN

... give more attention to religious topics

$25 \cdot 5$

32.3

23.7

... give space for conflicts on religion

72.0

$85 \cdot 3$

$74 \cdot 7$

... be critical on problematic aspects of rel.

75.8

80.8

71.2

... cover religion in satirical ways

65.0

68.1

$64 \cdot 3$

... invite dialogue when tension over rel.

72.3

81.0

$75 \cdot 5$

... cover Judaism more extensively

19.2

26.1

$27 \cdot 3$

... be more critical of Judaism

33.9

42.1

$33 \cdot 7$

... cover Christianity more extensively

$29 \cdot 3$

$33 \cdot 5$

32.8

... be more critical of Christianity

34.7

42.4

$35 \cdot 3$

... cover Islam more extensively

... be more critical of Islam

18.7

$24 \cdot 3$

$27 \cdot 3$

(N)

41.2

51.4

$43 \cdot 5$

(1006)

(1099)

(999)

Note: 'Don't know' and 'do not want to answer' included in the base.

statements, Norwegians are somewhat more in agreement with one another than are Danes and Swedes.

Humor and satire on religion - in entertainment media - is widely accepted, affirmed by two-thirds of Scandinavians. Upon further questioning, one-third of Scandinavians even fully or partly agree that statements scorning religion should be allowed. Again, such attitudes are somewhat more prominent among Norwegians than among Danes and Swedes.

When considering the world surrounding them, Scandinavians regard religion as leading to conflict rather than to peace. This sentiment is somewhat more widespread in Denmark than in the two other countries: eight out of ten Danes fully or partly agree. Only six percent of Danes disagree that religion leads to conflict rather than to peace (see Figure 3).

Since Scandinavians relate religion to conflict to such a large degree, it makes sense that they want the media to be critical of religion. This helps us understand that news concerning religion catches more interest among people than does information on religious practices and institutions. When religion becomes something to which people must be alert, as a contentious challenge to society and individual lives, it is understandable that people discuss religion that appears in the news, particularly news on religious extremism. 


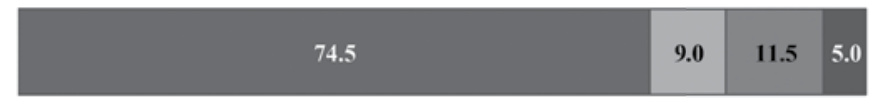

Sweden $(n=996)$

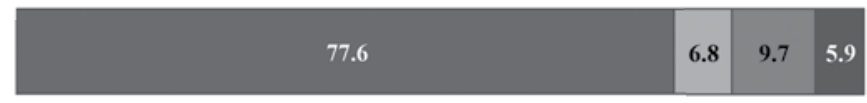

$\begin{array}{llllllllllll}0 \% & 10 \% & 20 \% & 30 \% & 40 \% & 50 \% & 60 \% & 70 \% & 80 \% & 90 \% & 100 \%\end{array}$

E Fully or partly agree $\square$ Neither/Nor $\square$ Fully or partly disagree $\square$ Don't know/No answer

FIGURE 3 Looking at the world, religion leads to conflict rather than to peace-percentages

Two-thirds of those who discuss news concerning religion in the media on a daily or weekly basis include news concerning religious extremism in such talks. Hence, some more than one-fourth of respondents discuss news on religious extremism daily or weekly (see Figure 4). Scandinavians' discussions concerning religion in the news thus center on (but are not exclusive to) religious extremism.

In what settings do Scandinavians discuss news on religious extremism? Generally, such discussions take place in close social contexts, at home with the family, with friends, at school or the workplace, or to some extent in cafés or similar social meeting places. However, some take discussions on religious extremism to the internet. ${ }^{18}$ While only around three percent of Scandinavians discussed religious extremism in commentary fields or online discussion forums during the previous twelve months, around nine percent did so on social media, like Twitter and Facebook. Furthermore, three-fifths of respondents who had participated in discussions concerning religion on social media reported that they had participated in debates concerning religious extremism. Extremism thus appears to be a major, though not necessarily dominant, concern among a plurality of those who discuss religion on the internet.

18 Alternatives given were: 'at home with the family'; 'with friends'; 'at work or school'; 'on social media (e.g. Facebook or Twitter)'; 'in commentary fields on online newspapers or in discussion forums on the internet'; 'in church or at other religious localities'; 'in cafés or other places where people go out'; 'don't know'; and 'no answer.' 


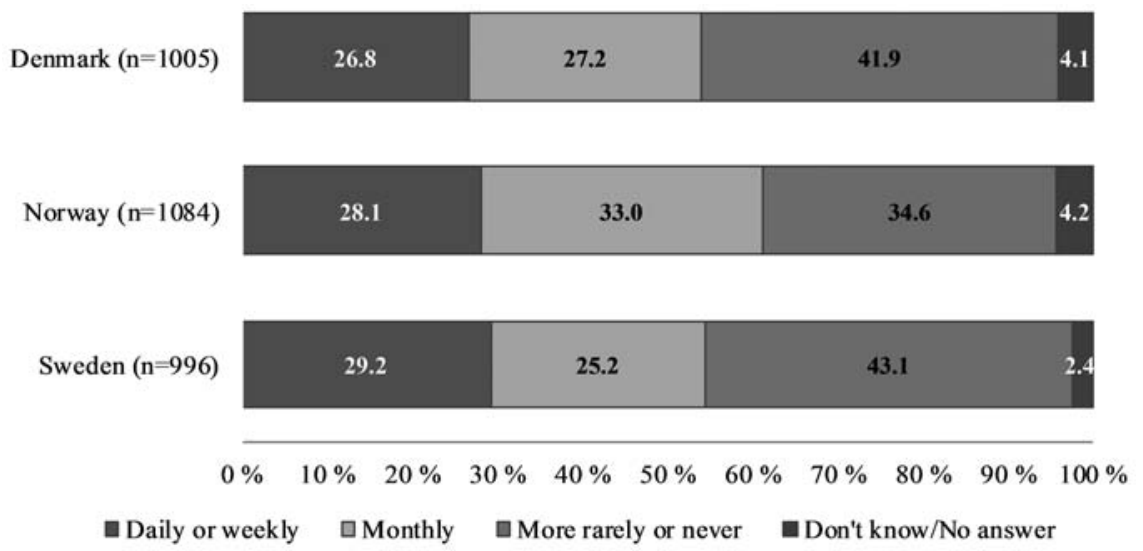

FIGURE 4 How often doyou discuss news on religious extremism with others?

Particularly in commentary fields and online discussion forums, other aspects of religion seem quite prevalent. Only one-third of respondents who had participated in discussions concerning religion in commentary fields and online discussion forums reported that they had participated in debates on religious extremism.

The concern about religious extremism is primarily directed towards Islam. This is also the case when it comes to the perceived negative influence of various religions on national culture. Nearly half of the Scandinavians in the survey see Islam as a threat to their national culture. However, some see even Christianity and Judaism as threats to the national culture. Some six to eight percent of Scandinavians regard Christianity as a threat, and around eleven percent regard Judaism as a threat.

When analyzing critical attitudes towards Islam, national differences come through. More than half of Danes fully or partly agree that Islam constitutes a threat to Danish culture. This is the case for four out of ten Swedes, with Norwegians positioned between the two others (see Figure 5). It is also important to note that we can identify a strong division in attitudes in all three countries: a large minority in all three countries either fully or partly disagree that Islam poses a threat to national culture: around thirty-one percent in Denmark, thirty-six percent in Norway, and forty-two percent in Sweden. Given the focus on Islam among our respondents, the remainder of this article 

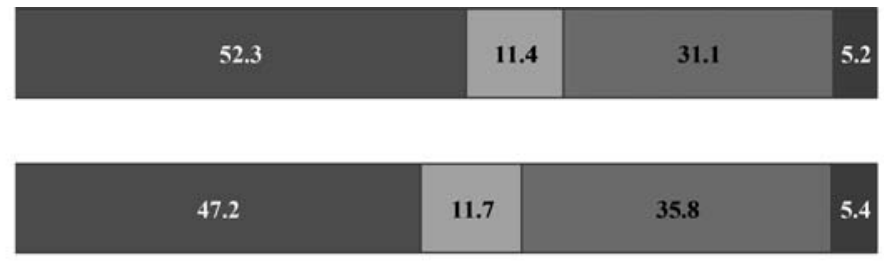

Sweden $(\mathrm{n}=985)$

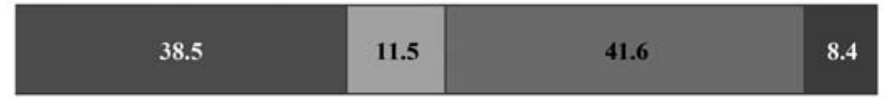

$\begin{array}{lllllllllll}0 \% & 10 \% & 20 \% & 30 \% & 40 \% & 50 \% & 60 \% & 70 \% & 80 \% & 90 \% & 100 \%\end{array}$

घully or partly agree $\square$ Neither/Nor $\square$ Fully or partly disagree $\square$ Don't know/No answer

FIGURE 5 Islam perceived as a threat to Danish/Norwegian/Swedish culture

will concentrate on the divergent attitudes among Scandinavians regarding Islam as a threat to national culture.

How does this perceived threat from Islam resonate among respondents in the survey? We asked the respondents whether they would tolerate hostile attitudes against foreigners. In all three countries, a majority were unwilling to tolerate such attitudes, the Swedes more clearly than their neighbors. Among them, the Danes are somewhat more tolerant to hostile attitudes towards foreigners than are the Norwegians (see Figure 6).

The sense that Islam poses a threat (see Figure 5) is much more prominent than is tolerance of hostile attitudes towards foreigners (see Figure 6). The Swedish respondents tolerate hostility towards foreigners and regard Islam as a threat to their culture to a lesser degree than do other Scandinavians. As shown in the previous section, a large majority of Scandinavians feel that religion leads to conflict rather than to peace (see Figure 3 ). This correlates positively in all three countries with the view of Islam as a threat to national culture. ${ }^{19}$ Thus, the conflictual view of religion appears to center on Islam.

The widespread perception that Islam poses a threat to national culture is not clearly associated with a general acceptance of hostility towards foreigners. On the contrary, in all three Scandinavian countries a majority of those who

19 The correlation (Pearson's r) is .327 in Sweden; .281 in Norway; and .215 in Denmark. All correlations are significant at the o.o1-level (two-tailed). 


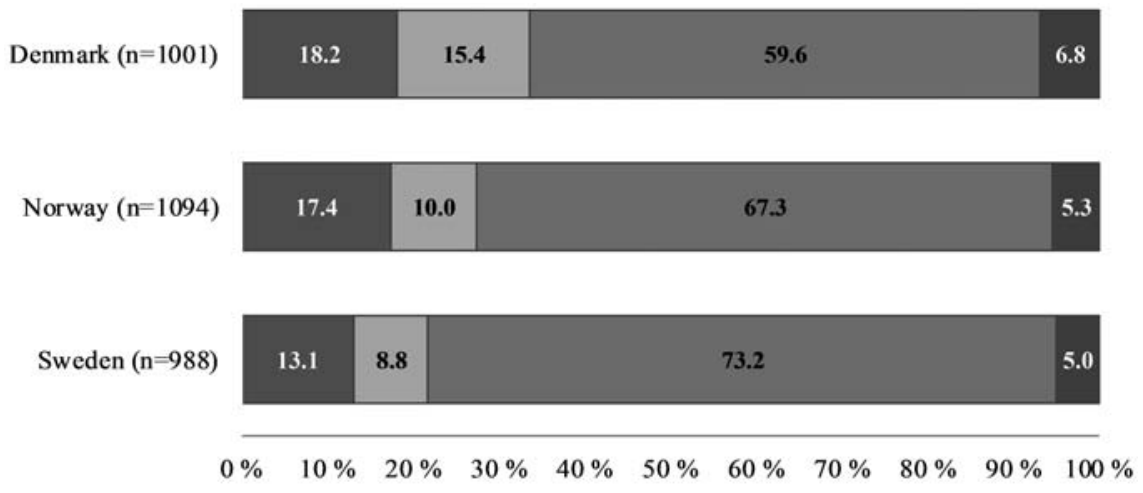

Eully or partly agree $\square$ Neither/Nor $\square$ Fully or partly disagree $\quad$ Don't know/No answer

FIGURE 6 Hostile attitudes against foreigners should be tolerated-percentages

consider Islam as a threat to their national culture do not accept hostile attitudes towards foreigners (see Figure 7).

Only one-quarter of those who perceive Islam as such a threat say that they fully or partly tolerate hostile attitudes towards foreigners. Among respondents having this position regarding the two questions, we find more men than women in all three countries. A critical perception of Islam is, therefore, not necessarily an index for hostility against foreigners. This is interesting, since public debates about these issues may tend to conflate the two questions. In particular, populist parties in all three Scandinavian countries have tried to use criticism of Islam as an argument to harden attitudes towards immigrants, but, for many Scandinavians, the coupling between perceptions of threats to national culture and attitudes towards foreigners seems to be less obvious and less directly connected than perhaps expected.

The relationship between tolerance of hostile attitudes against foreigners and perception of Islam as a threat to national culture is, however, not unrelated and if we look among those respondents who accept hostile attitudes they are positively correlated with each other. Within the minority of Scandinavians who agree that hostile attitudes towards foreigners should be tolerated, a majority (69.5\%) regard Islam as a threat to their national culture. ${ }^{20}$

20 There is a positive correlation (Pearson's $r$ ) between the two variables in all three countries: strongest in Sweden (.433), weakest in Denmark (.192), with Norway in the middle (.297). All correlations are significant at the o.o1-level (two-tailed). 


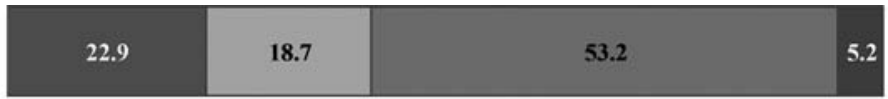

Norway $(\mathrm{n}=511)$

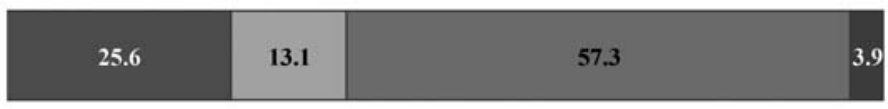

Sweden $(\mathrm{n}=378)$

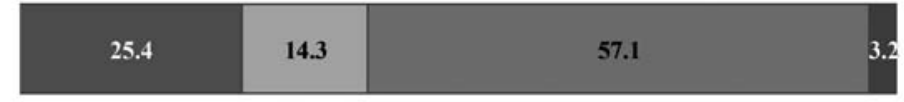

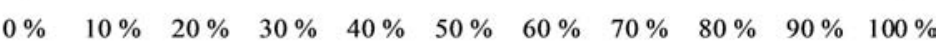

Eully or partly agree $\square$ Neither/Nor $\square$ Fully or partly disagree $\quad$ Don't know/No answer

FIGURE 7 Tolerance for hostile attitudes against foreigners among people considering islam a threat to national culture - percentages

In the combined Scandinavian sample, the inclination to (fully or partly) perceive Islam as a threat to national culture is stronger among men (fifty-two percent) than among women (forty-one percent). Similarly, this tendency becomes stronger with age (from thirty-five percent among Scandinavians under the age of thirty to fifty-three percent among those sixty years or older).

There is a substantial positive correlation between political orientation and Islam as a perceived threat to national culture, meaning that there is a tendency for those who vote for political parties that the cHEs survey identify as more traditional or authoritarian to also perceive Islam as a threat to their national culture and for those who vote for libertarian/post-materialist parties to perceive Islam as less of a threat. The correlation occurs in all three countries but is stronger in Sweden and Denmark than in Norway (Denmark: .456; Norway: .299; Sweden: .493). ${ }^{21}$ While this finding might fit our expectations, it is perhaps more surprising that there is practically no correlation between religious self-identification and perception of Islam as a threat to national cultures. As such, there appears to be little difference in attitudes regarding Islam depending on whether individuals possess stronger or weaker religious

21 All correlations (Pearson's r) are significant at the o.o1-level (two-tailed). Political orientation $=\mathrm{GAL} / \mathrm{TAN}$ score. Islam perceived as a threat to national culture: $1=$ fully disagree; 2 = partly disagree; 3 = neither $/$ nor; 4 = partly agree; and 5 = fully agree. The categories for Islam as a perceived threat are also employed in the following correlations in which this variable is employed. 
self-identification. This is the case for Norway (.057) and Sweden (.048) while there is a weak but significant correlation for Denmark (.146). ${ }^{22}$ In the case of Denmark, then, there seems to be a slight tendency for those with strong religious self-identification to also perceive Islam as a threat to Danish culture to a greater extent than do those possessing weaker religious self-identification.

\section{1 \\ Islam as a Perceived Threat and Discussion of Religion in Media}

As shown in Figure 4, Scandinavians frequently discuss news on religious extremism with others. However, in Denmark and Norway, there is essentially no correlation between the degree to which respondents perceive Islam as a threat to their national culture and the frequency with which they discuss religious extremism..$^{23}$ In other words, both proponents and opponents of this perceived threat engage in debate about religious extremism. Among Swedes, there is a weak but significant negative correlation $(-.135) \cdot{ }^{24}$ This implies that there is a slight tendency in Sweden for respondents who are most keen to discuss religious extremism in the news to also regard Islam as a threat to Swedish culture.

We may include all debates on religion in various online media, not just on religious extremism, in relation to the perceived threat from Islam. In Sweden and Norway, there seems to be no such correlation, while in Denmark there is a significant but weak positive correlation (0.081) between participation in online debates on religion and perception of Islam as a threat to Danish culture. ${ }^{25}$ Among Danes, there thus seems to be a very weak tendency for those who participate in online debates on religion to also perceive Islam as a threat to Danish culture to a greater extent than those who do not participate in online debates. ${ }^{26}$

The correlation (Pearson's $r$ ) for Denmark is significant at the o.o1-level (two-tailed). Religious self-identification: $0=$ no religious self-identification; $1=$ weak religious self-identification; $2=$ moderate religious self-identification; and $3=$ strong religious self-identification. The correlations for Norway and Sweden are not significant.

23 Denmark:-.051; Norway: .025.

24 This correlation (Pearson's $r$ ) is significant at the o.o1-level (two-tailed). Discussions concerning religious extremism: $1=$ daily or weekly; $2=$ monthly; and $3=$ more seldom or never.

25 This correlation is significant at the 0.05 -level (two-tailed). Participated in online debates on religion during the last year: $0=$ no; $1=$ yes.

26 The above correlations do not suggest a linear correlation between the selected variables, but there is some support for a curvilinear relationship. This implies that respondents who fully agree and fully disagree that Islam constitutes a threat to their national culture 
In this study, Denmark stands out as the most polarized and conflict-oriented country and Sweden as the most liberal and secular country when it comes to attitudes regarding religion. The Norwegians take a middle position. Whereas over half of Danes perceive Islam as a threat to Danish culture, this is the case for less than forty percent of Swedes.

These findings resonate with a comparative study of the relationship between national identity and religion in Denmark, Norway, and Sweden from $2013 .{ }^{27}$ This study showed that religious aspects, namely the importance of being a Christian in order to be a true citizen, as a vital part of national identity were most pronounced in Denmark. However, compared with other countries in Western Europe, religious nationalism holds a relatively weak position in all of the Scandinavian countries. The study concludes that Sweden and Norway are quite alike when it comes to dimensions of national identity. Denmark seems to most frequently be the deviant case. ${ }^{28}$

One possible interpretation of these differences is that they are results of different national policies, particularly regarding immigration from Muslim countries, but also in terms of specific national experiences, such as the cartoon crisis in Denmark. Furthermore, the international war on terror has provided an important context for developments of attitudes towards Islam and has been a major issue in the news media. Here, the Scandinavian countries have had different official policies regarding the military conflict. From 2001 and onwards, Denmark has taken a very active role in military operations in Afghanistan, Iraq, Libya, and Syria, and this has often been supported by the

to a large extent take part in online discussions concerning religion and also discuss religious extremism more often. However, these tendencies are trivial (the highest correlation is -.111) and not significant for all of the countries.

27 The survey, National Symbols 2013, involved 1500 representative samples of Norwegians, 1000 Danes, and 1000 Swedes and was conducted by KIFO through the bureau Norstat. Pål Ketil Botvar, "Does One Have to Be a Christian to Be Truly Norwegian? The Relationship Between Religion and National Identity," in: Anna-Sara Lind, Mia Lövheim, \& Ulf Zackariasson (eds.), Religion, Law and Democracy: New Challenges for Society and Research (Lund: Nordic Academic Press, 2016), 199-215.

28 Pål Ketil Botvar, "Scandinavian Folk Churches, Chauvinism and Xenophobia," in: Annika Hvithamar, Margit Warburg, \& Brian Arly Jacobsen (eds.), Holy Nations and Global Identities: Civil Religion, Nationalism, and Globalization (Leiden: Brill, 2009), 183-198; Botvar, "Does One Have to Be a Christian." 
news media. ${ }^{29}$ Sweden has, comparatively speaking, been less involved in prolonged military action, while Norway represents a mid-level military engagement among the three countries. The representation of Islamic terrorism in news media during these wars may also, in various ways, come to influence general attitudes towards religion and refugees. Although there are such differences between the three countries, the overall similarities in Scandinavia are more striking. The three countries, after all, share much of the same religious history and have similar political and media systems, strongly embedded within the Scandinavian model of welfare societies.

\section{Politicized Islam and Mediatized Religion}

Our results generally reflect that Islam has become a highly politicized issue that divides public opinion in significant ways. General political fault lines tend to coincide with attitudes towards Islam: respondents with traditional or authoritarian political values are more prone to think of Islam as a threat, whereas respondents with libertarian and post-materialist values more often reject this idea. In general, religious self-identification plays a less important role for the formation of these general attitudes towards Islam. In this respect, basic political orientations are more important than religious orientations.

Our analysis has focused on controversies regarding Islam, politics, and the media, but it is worth recalling that our survey also covered questions concerning other religions and non-political aspects regarding religion in the media. However, respondents show only limited interest in media coverage of other aspects of religion, such as moral reflection or worship and devotion. They strongly support the media's role of providing space for reporting and discussions concerning conflicts involving religion, as well as taking a critical stance towards problematic aspects of religion, including providing satire of religion. Respondents also recognize the media's role as possible arbitrators of conflicts by supporting the media in initiating dialogue in case of tension over religious issues. Furthermore, news media reporting is a frequent source of discussions concerning religious extremism, and social media and other online media represent venues in which some people discuss religious issues, albeit not to the same extent as in familiar contexts, such as the home or the workplace, which remain the preferred contexts for such discussions. These results indicate that, when it comes to news reporting and public debate concerning

29 Stig Hjarvard \& Nete Nørgaard Kristensen, "When Media of a Small Nation Argue for War," Media, War \& Conflict 7/1 (2014), 51-69. 
religion, religion is a mediatized phenomenon at the level of interests and attitudes. News media are not just an important source of information concerning religion; respondents' interests in and attitudes towards religious issues seem to be very much in accordance with general journalistic news values and the news media's role as a critical watchdog in society.

The results of this survey provide a basis for the hypothesis that politicization of Islam and mediatization of religion are mutually reinforcing processes. The politicization of Islam makes it more newsworthy and thus visible in the public sphere, and the mediatization of religion involves the news media's construction of Islam as a conflict-ridden topic, so that less attention is paid to other dimensions of this religion. Even though Islam is perceived by many as a threat to the cultures of Scandinavian countries, respondents show limited interest in news media reporting on cultural, spiritual, or other aspects of religion, and respondents' discussions concerning religion are oriented towards the political and conflict-ridden dimensions of Islam. Not only news media and politics seem to work in tandem to represent Islam in contentious ways, but also other forms of media dynamics in, for instance, social network media add to this politicized and critical perception of Islam. It is, however, beyond the scope of this predominantly descriptive study (based on a single comparative survey on attitudes) to further substantiate such a hypothesis regarding the reciprocity of politicization and mediatization.

Our comparative study on media, politics, and religion suggests that, despite common characteristics, Scandinavian countries display some notable differences. To what extent these differences will grow or diminish in the future is difficult to say since this study does not report developmental trends. However, given the current refugee crises and its political repercussions at both $\mathrm{EU}$ and national levels, the intensified war on terror, and the rising influence of populist parties, it seems likely that Islam will continue to be high on the agenda of both politics and news media and that the interplay between media and politics may amplify existing attitudinal differences within individual Scandinavian countries and perhaps also between them.

\section{References}

Bakker, Ryan, et al., 2014 Chapel Hill Expert Survey —Version 2015.1 (Chapel Hill: University of North Carolina, 2015). http://chesdata.eu/2014/2014_CHES_codebook.pdf (accessed 18 April 2017).

Botvar, Pål Ketil, "Does One Have to Be a Christian to Be Truly Norwegian? The Relationship Between Religion and National Identity," in: Anna-Sara Lind, Mia Lövheim, 
\& Ulf Zackariasson (eds.), Religion, Law and Democracy: New Challenges for Society and Research (Lund: Nordic Academic Press, 2016), 199-215.

Botvar, Pål Ketil, "Scandinavian Folk Churches, Chauvinism and Xenophobia," in: Annika Hvithamar, Margit Warburg, \& Brian Arly Jacobsen (eds.), Holy Nations and Global Identities: Civil Religion, Nationalism, and Globalization (Leiden: Brill, 2009), 183-198.

Damgaard, Erik, "Parliamentary Change in the Nordic Countries," in: Erik Damgaard et al. (eds.), Parliamentary Change in the Nordic Countries (Oslo: Scandinavian University Press, 1992), 191-205.

Hjarvard, Stig, The Mediatization of Culture and Society (London: Routledge, 2013).

Hjarvard, Stig, \& Nete Nørgaard Kristensen, "When Media of a Small Nation Argue for War," Media, War \& Conflict 7/1 (2004), 51-69.

Hjarvard, Stig, \& Mia Lövheim (eds.), Mediatization and Religion: Nordic Perspectives (Gothenburg: Nordicom, 2012).

Ivanescu, Carolina, "Politicised Religion and the Religionisation of Politics," Culture and Religion 11/4 (2010), 309-325.

Lindberg, Jonas, Religion in Nordic Politics as a Means to Societal Cohesion: An Empirical Study on Party Platforms and Parliamentary Debates 1988-2012. Studies in Religion and Society 13 (Uppsala: Acta Universitatis Upsaliensis, 2015).

Lundby, Knut (ed.), Mediatization of Communication. Handbooks of Communication Science 21 (Berlin: De Gruyter Mouton, 2014).

Lundby, Knut (ed.), Contesting Religion: The Media Dynamics of Cultural Conflicts in Scandinavia (Berlin: De Gruyter, forthcoming 2018).

Lundby, Knut, \& Salve Jortveit, Dokumentasjon av CoMRel survey april 2015. www .hf.uio.no/imk/english/research/projects/comrel/comrel-survey-dokumentasjon. pdf (accessed 18 April 2017).

Lundby, Knut, et al., "Religion and the Media: Continuity, Complexity and Mediatization," in: Inger Furseth (ed.), Religious Complexity in the Public Sphere: Comparing Nordic Countries (Basingtoke: Palgrave Macmillan, 2018), Chapter 5.

Lövheim, Mia, "Mediatization and Religion," in: Knut Lundby (ed.), Mediatization of Communication. Handbooks of Communication Science 21 (Berlin: De Gruyter Mouton, 2014), 547-570.

Migrationsinfo.se. http://www.migrationsinfo.se/migration/sverige/ (accessed 18 April 2017).

Niemelä, Kati, \& Henrik Reintoft Christensen, "Religion in Newspapers in the Nordic Countries in 1988-2008," Nordic Journal of Religion and Society 26/1 (2013), 5-24.

Pettersen, Silje Vatne, \& Lars Østby, "Skandinavisk komparativ statistikk om integrering: Innvandrere i Norge, Sverige og Danmark," Samfunnsspeilet 27/5 (2013), 76-82.

World Values Survey. http://www.worldvaluessurvey.org/WVSContents.jsp (accessed 18 April 2017). 